\title{
Cell Surface Proteoglycans as Potential Targets for Immunotherapy in Women's Cancer
}

\author{
Julianna Slavik ${ }^{1}$, Rebecca Clancy ${ }^{1}$, William Yarina ${ }^{1}$, Mary Lou Cutler ${ }^{2,4}$, Craig D Shriver ${ }^{3,4}$ and Joji Iida ${ }^{1,4 *}$ \\ ${ }^{1}$ Department of Cell Biology, Chan Soon-Shiong Molecular Medicine at Windber, Windber, USA \\ ${ }^{2}$ Department of Pathology, Uniformed Services University for Health Sciences, Bethesda, USA \\ ${ }^{3}$ Department of Surgery, Walter-Reed National Military Medical center, Bethesda, USA \\ ${ }^{4}$ Murtha Cancer Center, Bethesda, USA
}

Submission: September 20, 2017 ; Published: October 05, 2017

*Corresponding author: Joji Iida PhD. Department of Cell Biology, Chan Soon-Shiong Molecular Medicine atWindber, Windber, PA 15963, USA, Tel: 814-361-6985; Fax: (814)-467-6334; Email g.iida@wriwindber.org

\begin{abstract}
Proteoglycans (PGs) are family of glycoproteins composed of core proteins modified by heparan and chondroitin sulfate glycosaminoglycans. During the multiple processes of the tumor-host interaction, the glycosaminoglycan moiety regulates biological functions through the interaction with different protein ligands including soluble factors and ligands expressed on the other cells. In addition, increasing evidence demonstrates that core proteins transduce signals as well as interact with the cytoskeleton elements that regulate migration and invasion. Given the diversity of functions of cell surface PGs in facilitating cancer progression and metastasis, recent studies in animal models suggest that targeting cell surface PGs is a promising approach to inhibit growth and metastasis of cancer cells. In this review, we will discuss the recent advances of cell surface PGs in cancer biology and utilize them as therapeutic targets in women's cancer.
\end{abstract}

Keywords: Cell adhesion; ECM; Proteoglycan; Integrin; Breast; Immunotherapy

Abbrevations: ECM: Extra Cellular Matrix; PG: Proteo Glycan; CS: Chondroitin; HS: Heparan; GAG: Glycos Amino Glycan

\section{Introduction}

Triple negative breast cancers constitute approximately $15-20 \%$ of all breast cancers and they are more aggressive compared to other phenotypes (e.g. Luminals A and B and Her2+). Additionally, triple negative breast cancers are harder to treat because of the absence of targets for hormonal therapies such as ER, PR, and Her2+. Presently, there are only limited neoadjuvant therapy regimens available that weaken or shrink triple negative breast cancer cells prior to surgical resection. Thus, one immediate requirement for the treatment of triplenegative breast cancer is to characterize and evaluate molecules that play important roles in promoting malignant phenotypes and to develop novel strategies that interfere with the functions of these proteins.

\section{Discussion}

Given that cancer cells must transverse surrounding tissues to establish metastases, the interaction of cancer cells with host derived components such as extracellular matrix (ECM) are key steps for facilitating this process [1]. Cell surface proteoglycans
(PGs) consists of core proteins with covalently attached heparan (HS) or chondroitin (CS) sulfate glycosaminoglycans (GAGs), which associate with the cell membrane through trans membrane domain or GPI-linkage (Table1). There are lines of evidence demonstrating that PGs are key molecules in facilitating cancer progression and metastasis by regulating cell-to-ECM, cell-tocell, and cell-to-soluble factors interactions in the cancer/host tissue in a cancer cell-specific manner.

Table 1: Cell surface proteoglycans (PGs) expressed on cancer cells.

\begin{tabular}{|c|c|c|c|}
\hline Protein & Modificationa & $\begin{array}{c}\text { Size of Core } \\
\text { Proteinb }\end{array}$ & Anchor \\
\hline CD44 & HS/CS & vary & TMc \\
\hline CSPG4 & CS & 220 & TM \\
\hline $\begin{array}{c}\text { Syndecans (1 } \\
\text { thorugh4) }\end{array}$ & HS/CS & 50 & TM \\
\hline $\begin{array}{c}\text { Glypicans (1 } \\
\text { through 5) }\end{array}$ & HS & 80 & GPId \\
\hline
\end{tabular}




\begin{tabular}{|c|c|c|c|}
\hline Betaglycan & HS/CS & 90 & TM \\
\hline $\begin{array}{c}\text { PTPろ } \\
\text { (Phosphacan) }\end{array}$ & CS & 250 & TM \\
\hline
\end{tabular}

i.HS: heparan sulfate.

ii.CS: chondroitin sulfate.

iii.Apparent molecular weights on SDS-PAGE after digestion with chondroitinase $\mathrm{ABC}$ or

heparitinase or both of them

iv. Transmemembrane domain

v.Glycosylphosphatidylinositol

a: HS: heparan sulfate. CS: chondroitin sulfate.

b: Apparent molecular weights on SDS-PAGE after digestion with chondroitinase $\mathrm{ABC}$ or

heparitinase or both of them

c: Transmemembrane domain

d: Glycosylphosphatidylinositol

The functional diversity of cell surface PGs is a result of the structural diversity in both core proteins and GAGs, as well as their localizations on the cell surface. Thus, further characterization of cell surface PGs expressed on cancer cells should lead to development of novel therapeutic strategies to inhibit cancer progression and metastasis. Since CSPG4 (chondroitin sulfate proteoglycan 4, NG2, MCSP, HMW-MAA) was first identified as a specific antigen expressed on human malignant melanoma cell surface [2], it has been evaluated as a key molecule to regulate malignant phenotypes. For example, CSPG4 expressed on malignant melanoma cells scaffolds and co-localizes matrix metalloproteinases such as MMP-2 and MMP-16thus promoting invasion by facilitating pericellular matrix degradation $[3,4]$.

CSPG4 enhances cell adhesion to ECM by binding to integrins and transducing signals including tyrosine kinases and small GTPases to regulate integrin-mediated signaling pathway [56]. In breast cancer, CSPG4 has been characterized not only as a marker for breast cancer stem cells but also as a functional molecule to promote progression and metastasis. We previously demonstrated that CSPG4 forms a complex with a metastasispromoting protein, NEDD9, in triple-negative breast cancer cells and regulates three-dimensional cancer growth $[7,8]$. Chondroitin sulfate glycosaminoglycan expressed on CSPG4 core protein serve as a ligand for P-selectin expressed on endothelial cells and removal of the glycans from malignant breast cancer cells reduced metastatic foci in the lungs $[9,10]$.

Importantly, studies using a function-blocking antibody against CSPG4 core protein provide direct evidence demonstrating that targeting CSPG4 is a promising approach to inhibit breast cancer growth and more importantly that it diminishes already established metastatic foci in lungs [11]. These studies led to engineering T-cells to specifically recognize and kill CSPG4+ tumor cells by expressing CSPG4 antibody-chimeric antigen receptor (CAR) [12-14]. This is an attractive approach for killing not only tumor cells but also CSPG4+ pericytes, which are precursors of endothelial cells. Given that CSPG4 is expressed on host derived normal cells such as glia cells [15], it is important to minimize potential of-target effects by engineering the CSPG4 CAR engineered T-and/or NK-cells with a suicide pathway that can induce their apoptosis. This is accomplished with vectorencoded HSV thymidine kinase or constitutively active caspases under inducible promoters. In spite of the complexities of the approach, targeting CSPG4 is a promising therapeutic strategy for the future in combination with other therapeutic strategies.

\section{Conclusion and Perspectives}

There are several studies demonstrating the efficacy of targeting cell surface PGs for inhibiting growth and metastasis. For example, previous studies demonstrated that the disruption of the complex of syndecan- 1 with $\alpha v \beta 3$ and $\alpha v \beta 5$ integrins resulted in significant tumor growth and tumor-induced angiogenesis of mammary carcinoma cells [16,17]. Reagents targeting CD44-hyaluronan (HA) interaction in cancer therapies have been developed for use in clinical studies [18]. Glypican-3 was identified as a potential target for immunotherapy in hepatocellular carcinoma and injection of humanized antibody against glypican-3 demonstrated efficacy to inhibit tumor growth in mouse model systems $[19,20]$.

Given the diverse functions of cell surface PGs as "fine tuners" in regulating cancer growth, migration, and invasion in host microenvironments, the targeting of these molecules as therapeutic strategies will provide not only significant benefits for patients but also significant insights for understating cancer biology.

\section{Acknowledgement}

These works were supported by a grant from the United States Army Medical Research Acquisition Activity (USAMRAA) (Breast Cancer Translational Research: W81XWH-12-2-0050), Department of Energy (contract \#183030), and partially by USMCI (MDA-905-02-2-0005). This study was approved by the Institutional Review Board, Walter Reed National Military Medical Center. The opinion and assertions contained herein are the private views of the authors and are not to be construed as official or as representing the views of the Department of the Army or the Department of Defense.

\section{References}

1. Wang K, Wu F, Seo BR, Fischbach C, Chen W, et al. (2016) Breast cancer cells alter the dynamics of stromal fibronectin-collagen interactions. Matrix Biol.

2. Pluschke G, Vanek M, Evans A, Dittmar T, Schmid P, et al. (1996) Molecular cloning of a human melanoma-associated chondroitin sulfate proteoglycan. Proc Natl Acad Sci USA 93(18): 9710-9715.

3. Iida J, Pei D, Kang T, Simpson MA, Herlyn M, et al. (2001) Melanoma chondroitin sulfate proteoglycan regulates matrix metalloproteinasedependent human melanoma invasion into type I collagen. J Biol Chem 276(22): 18786-18794. 
4. Iida J, Wilhelmson KL, Ng J, Lee P, Morrison C, et al. (2007) Cell surface chondroitin sulfate glycosaminoglycan in melanoma: role in the activation of pro-MMP-2 (pro-gelatinase A). Biochem J 403(3): 553563.

5. Eisenmann KM, McCarthy JB, Simpson MA, Keely PJ, Guan JL, et al. (1999) Melanoma chondroitin sulphate proteoglycan regulates cell spreading through Cdc42, Ack-1 and p130cas. Nat Cell Biol 1(8): $507-$ 513.

6. Yang J, Price MA, Neudauer CL, Wilson C, Ferrone S, et al. (2004) Melanoma chondroitin sulfate proteoglycan enhances FAK and ERK activation by distinct mechanisms. J Cell Biol 165: 881-891.

7. Iida J, Dorchak J, Clancy R, Slavik J, Ellsworth R, et al. (2015) Role for chondroitin sulfate glycosaminoglycan in NEDD9-mediated breast cancer cell growth. Exp Cell Res 330(2): 358-370.

8. Iida J, Dorchak J, Lehman JR, Clancy R, Luo C, et al. (2012) FH535 inhibited migration and growth of breast cancer cells. PLoS One 7(9): e44418.

9. Cooney CA, Jousheghany F, Yao-Borengasser A, Phanavanh B, Gomes T, et al. (2011) Chondroitin sulfates play a major role in breast cancer metastasis: a role for CSPG4 and CHST11 gene expression in forming surface P-selectin ligands in aggressive breast cancer cells. Breast Cancer Res 13(3): R58.

10. Monzavi Karbassi B, Stanley JS, Hennings L, Jousheghany F, Artaud C, et al. (2007) Chondroitin sulfate glycosaminoglycans as major P-selectin ligands on metastatic breast cancer cell lines. Int J Cancer 120(6): 1179-1191.

11. Wang X, Osada T, Wang Y, Yu L, Sakakura K, et al. (2010) CSPG4 protein as a new target for the antibody-based immunotherapy of triplenegative breast cancer. J Natl Cancer Inst 102(19): 1496-1512.

12. Beard RE, Zheng Z, Lagisetty KH, Burns WR, Tran E, et al. (2014)
Multiple chimeric antigen receptors successfully target chondroitin sulfate proteoglycan 4 in several different cancer histologies and cancer stem cells. J Immunother Cancer 2: 25.

13. Burns WR, Zhao Y, Frankel TL, Hinrichs CS, Zheng Z, et al. (2010) A high molecular weight melanoma-associated antigen-specific chimeric antigen receptor redirects lymphocytes to target human melanomas. Cancer Res 70(8): 3027-3033.

14. Wang Y, Geldres C, Ferrone S, Dotti G (2015) Chondroitin sulfate proteoglycan 4 as a target for chimeric antigen receptor-based T-cell immunotherapy of solid tumors. Expert Opin Ther Targets 19(10): 1339-1350.

15. Huang W, Zhao N, Bai X, Karram K, Trotter J, et al. (2014) Novel NG2CreERT2 knock-in mice demonstrate heterogeneous differentiation potential of NG2 glia during development. Glia 62: 896-913.

16. Beauvais DM, Burbach BJ, Rapraeger AC (2004) The syndecan-1 ectodomain regulates alphavbeta3 integrin activity in human mammary carcinoma cells. J Cell Biol 167(1): 171-181.

17. Beauvais DM, Ell BJ, McWhorter AR, Rapraeger AC (2009) Syndecan-1 regulates alphavbeta3 and alphavbeta5 integrin activation during angiogenesis and is blocked by synstatin, a novel peptide inhibitor. J Exp Med 206(3): 691-705.

18. Mattheolabakis G, Milane L, Singh A, Amiji MM (2015) Hyaluronic acid targeting of CD44 for cancer therapy: from receptor biology to nanomedicine. J Drug Target 23(7-8): 605-618.

19. Fleming BD, Ho M (2016) Glypican-3 Targeting Immunotoxins for the Treatment of Liver Cancer. Toxins (Basel) 8(10).

20. Zhang YF, Ho M (2016) Humanization of high-affinity antibodies targeting glypican-3 in hepatocellular carcinoma. Scientific Reports 6: Article. No. 33878.

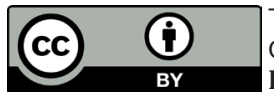

This work is licensed under Creative

Commons Attribution 4.0 Licens

DOI: $10.19080 / J G W H .2017 .07 .555709$

\section{Your next submission with Juniper Publishers} will reach you the below assets

- Quality Editorial service

- Swift Peer Review

- Reprints availability

- E-prints Service

- Manuscript Podcast for convenient understanding

- Global attainment for your research

- Manuscript accessibility in different formats

( Pdf, E-pub, Full Text, Audio)

- Unceasing customer service

Track the below URL for one-step submission https://juniperpublishers.com/online-submission.php 